\title{
Pemanfaatan Lahan Pekarangan Untuk Budidaya Sayuran Organik di Desa Kediri Kabupaten Banyumas
}

\author{
Indah Setiawati ${ }^{1 *}$, Rosi Widarawati ${ }^{2}$, Pepita Haryanti $^{3}$, Okti Herliana $^{2}$, \\ Irene Kartika Ekawati ${ }^{1}$ \\ ${ }^{1}$ Laboratorium Pemasaran Agribisnis, ${ }^{2}$ Laboratorium Agroteknologi, ${ }^{3}$ Laboratorium Ilmu \\ dan Teknologi Pangan Fakultas Pertanian Universitas Jenderal Soedirman \\ J1. Profesor Dr. HR Boenyamin No.708 Grendeng Purwokerto Utara Banyumas 53122 \\ Jawa Tengah \\ "E-mail : iindahs@unsoed.ac.id \\ DOI: https://doi.org/10.21107/pangabdhi.v7i1.8656 \\ Naskah diterima 24 September 2020, Revisi 18 Februari 2021, Terbit 29 April 2021
}

\begin{abstract}
The science and technology application activities are planned to be carried out with the partner of the women farmer group located in Kediri Village, Karanglewas District. The problems faced by partners are not having adequate knowledge about natural pest management and the correct use of organic fertilizers; do not have skills in making and using vegetable pesticides, liquid organic fertilizers, and proper organic vegetable cultivation techniques. The purpose of applying science and technology is to provide knowledge about the functions and ways of using vegetable pesticides and liquid organic fertilizers, improving skills in making and using vegetable pesticides, POC, technical complete package of organic vegetable cultivation. Methods for achieving the goal are socialization and learning by doing, which are complemented by guiding and piloting techniques. The output of the service activities is in the form of articles in dedication journals, and articles on appropriate technology (TTG).
\end{abstract}

Keywords : women farmer grup, organic fertilizers, technology, pest management

\section{PENDAHULUAN}

Taman indah di sekitar rumah akan mampu membangkitkan semangat dan memberi inspirasi bagi yang memandang. Sebuah pepatah Cina kuno "Apabila ingin bahagia selama hidup, buatlah taman yang indah". Pepatah ini ada benarnya mengingat arti penting taman dalam sebuah rumah tinggal (Supriati et al., 2008). Sampai saat ini, lahan pekarangan di Desa Kediri belum dimanfaatkan untuk kegiatan yang produktif.

Sebagian besar lahan pekarangan ditanami sayuran dan buah-buahan khususnya tanaman pisang. Sayuran yang ditanam adalah caisim, terong, kelor, dan cabai. Penanaman sayuran dikelola secara organik dengan menggunakan pupuk kotoran kambing dan tanpa pestisida sintetis. Penanaman ini masih diusahakan dalam skala yang sempit dan belum dilakukan perawatan yang intensif, karena tujuan mereka hanyalah untuk konsumsi rumah tangga. Sayuran caisim, terong, dan cabai sudah berproduksi dan hasilnya dapat dimanfaatkan untuk konsumsi sendiri dan sebagian dibagikan kepada para tetangga. Kualitas sayuran yang dihasilkan kurang begitu bagus. Daun caisim banyak yang berlubang dimakan ulat dan belalang. Kendala musim berupa curah hujan yang tinggi dan tiba-tiba panas, sering membuat tanaman stress. Bibit tanaman yang masih kecil seringkali banyak yang rusak akibat terguyur air hujan. Sebenarnya para anggota ingin mengusahakan green house yang sederhana untuk mengatasi gangguan musim yang kurang menentu, namun mereka belum begitu paham bentuk green house yang optimal. Dengan demikian sampai saat ini kenginan memiliki green house belum terwujud, sehingga sayuran organik hanya diupayakan secara terbuka. Akibatnya hasil produksinya tidak maksimal dalam hal kuantitas maupun kualitas. Kendala yang dihadapi selama ini adalah masalah teknis budidaya.

Tuntutan masyarakat terhadap produk pertanian yang lebih sehat dan ramah lingkungan mendorong para pengurus kelompok wanita tani untuk membuat warung hidup organik di lahan pekarangan dengan memberdayakan para anggotanya yang tidak memiliki pekerjaan formal. Warung hidup organik adalah penanaman sayuran secara organik. Sayuran organik menjadi pilihan utama untuk dikembangkan karena teknik 
pemeliharaannya relatif mudah, harga jualnya lebih mahal dibanding sayuran anorganik, dan dapat ditanam dimana saja dengan siklus perputaran produksinya cepat (Sutariati et al., 2018). Tujuan awal pembuatan warung hidup adalah untuk memenuhi kebutuhan warga setempat akan sayuran organik yang aman dan bergizi. Apabila nantinya usaha ini semakin berkembang, maka anggota KWT ingin menjadikan usaha ini sebagai kegiatan produktif untuk menambah kas kelompok dan menambah penghasilan anggota. Menurut hasil wawancara dari beberapa anggota KWT, kendala yang dirasakan dalam pengembangan sayuran organik adalah pengalaman budidaya tanaman yang relatif kurang.

\section{METODE}

Kegiatan Pengabdian kepada Masyarakat ini dilaksanakan pada bulan Maret - September 2020 dengan Mitra kegiatan kelompok wanita tani Gelombang Cinta Desa Kediri Kecamatan Karanglewas, Banyumas. Bahan yang digunakan dalam kegiatan ini adalah benih caisim, benih kangkung, benih pakcoy, bibit tanaman mint, pupuk organik cair Bio2000Z, bawang putih, cabai rawit merah, dan tembakau. Alat yang digunakan dalam kegiatan ini adalah: polibag, tray semai, dan penyemprot.

Metode yang digunakan untuk menyelesaikan persoalan mitra dalam kegiatan Program Penerapan Ipteks adalah sosialisasi, alih teknologi, pelatihan, praktek dan pembuatan demplot (percontohan) serta pendampingan dengan pendekatan Partisipatory Rural Appraisal (PRA), yaitu melibatkan partisipasi masyarakat secara aktif dalam setiap pelaksanaan kegiatan. Selanjutnya dilakukan pendampingan dan evaluasi. Tahapan pelaksanaan kegiatan meliputi: sosialisasi, penyuluhan, pelatihan dan praktek dengan materi sebagai berikut:

a. Teknik budidaya sayuran secara organik dengan aplikasi pupuk organik cair Bio2000Z.

b. Teknik pengendalian hama penyakit tanaman sayuran secara terpadu dengan biopestisida berbahan baku sumberdya lokal dan agensia hayati.

\section{HASIL DAN PEMBAHASAN}

Kegiatan pengabdian kepada masyarakat "Program Penerapan Ipteks" pendampingan terhadap kelompok tani "Gelombang Cinta" dalam menjalankan kegiatan budidaya dan penjualan produk sayuran organik mendapat sambutan yang positif dari seluruh anggota kelompok, perangkat desa dan pemerintah daerah Kabupaten Banyumas. Kegiatan diawali dengan sosialisasi dan koordinasi terkait program yang akan dijalankan supaya tim pengabdi mendapatkan masukan dan informasi secara langsung terkait permasalahan yang dihadapi mitra. Pemanfaatan pekarangan mengandung nilai pendidikan khususnya dapat mendidik anggota keluarga cinta lingkungan, juga pekarangan dapat menjadi laboratorium hidup (Saptono, 2008).

Sosialisasi dan pemetaan permasalahan dilakukan tanggal 5 Mei 2020 Berdasarkan observasi dan diskusi langsung dengan anggota kelompok dapat dipetakan permasalahan yang dihadapi adalah: (1) ketersediaan pupuk organik; (2) keberadaan hama penyakit tanaman seperti ulat, belalang, dan karat daun; (3) permintaan pasar tidak terpenuhi karena keterbatasan produksi; (4) manajemen usaha dan kelompok perlu pembenahan; (5) pengetahuan teknologi pengolahan tanaman kelor yang masih rendah.

Kegiatan dilanjukan dengan penyuluhan dan pelatihan budidaya sayuran organik. Pemberian kegiatan pelatihan aplikasi penggunaan pupuk organik cair, pestisida nabati, dan teknis budidaya sayuran organik di lahan pekarangan milik pengurus KWT. Pelatihan dilaksanakan dengan membuat demplot dan sebagai kontrol adalah lahan yang sudah ditanami sayuran organik sebelumnya. Pada lahan demplot tersebut, para peserta dapat melihat dan ikut mempraktekkan materi yang diberikan.

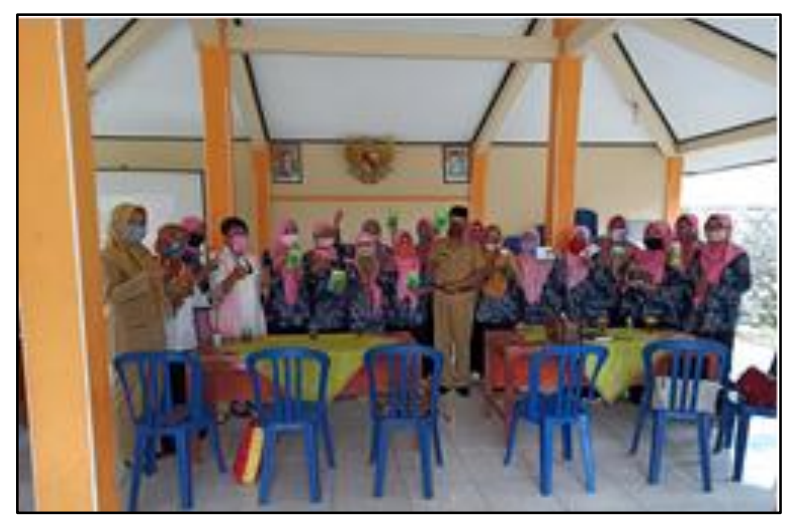

Gambar 1. Penyuluhan dan Pemberian Bantuan Benih dan Pupuk Bio2000Z

Pemberian materi atau penyuluhan dilakukan secara formal dan informal. Secara formal dilakukan dengan ceramah dan diskusi di suatu tempat yang telah disepakati, di sini dijelaskan paket teknologi lengkap dengan alat-alat peraga, 
sesuai dengan yang akan digunakan dalam demplot. Penyuluhan informal dapat dilakukan di mana saja, pendekatan bersifat lebih personal dan mungkin masalah yang dibicarakan juga sifatnya lebih parsial.

Dalam pelaksanaan demplot, semua peserta dilibatkan pada setiap kegiatan. Peserta mulamula diberi penjelasan tentang teknik pelaksanaan, alasan teoretis - praktis, akibat kesalahan teknik pelaksanaan dan dan sebagainya. Setelah diberikan contoh, selanjutnya kepada peserta diminta untuk mencoba melakukan sendiri, sambil tetap dibimbing. Selanjutnya pelaksanaan seluruh tahap pekerjaan dalam budidaya sayuran mulai pengolahan lahan sampai panen, aplikasi penggunaan pupuk organik cair Bio2000Z, dan pestisida nabati diserahkan kepada para peserta dengan tetap di bawah bimbingan dan pengawasan tim pengabdian dari Unsoed. Dengan cara ini, peserta dapat makin menguasai teknologi yang diinovasikan, baik secara teori maupun praktik, sehingga kalau diperlukan akan dapat pula menjelaskan kepada orang lain.

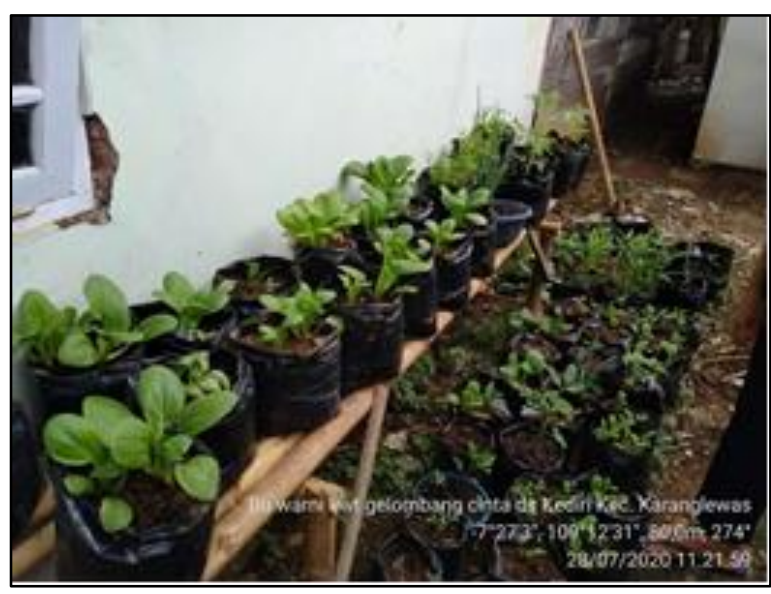

Gambar 2. Tanaman Sayuran Organik di Salah

Satu Pekarangan Rumah Anggota KWT

Kegiatan penyuluhan dan diseminasi teknologi ini bersifat simultan, artinya berlangsung sejak awal periode pertumbuhan tanaman sampai panen. Jenis sayuran yang berbeda dipanen pada waktu yang berbeda (Saptono dan Andoko, 2008). Demplot budidaya sayuran organik yang akan dilaksanakan sebagai berikut:

a. Pembuatan lahan demplot dan lahan kontrol di lahan milik pengurus KWT.

b. Penanaman komoditas sayuran menggunakan polibag untuk menanam empat macam komoditas sayuran (kangkung darat, caisim, pakcoy, dan kembang kol).

c. Demplot aplikasi penggunaan pupuk organik cair dilakukan di lahan demplot.
Pupuk yang digunakan adalah pupuk organik cair Bio2000Z. Sebagai kontrol adalah aplikasi penggunaan pupuk kotoran kambing tanpa pengolahan. Dendy (2014) menyatakan bahwa interval waktu penyemprotan 10 hari sekali dengan pupuk P2000Z akan memberikan hasil maksimal pada tanaman caisim. Menurut Komaruddin (2014), menunjukkan bahwa kombinasi perlakuan yang terbaik adalah pupuk organik cair konsentrasi 10,5\% dengan jarak tanam $(35 \times 35) \mathrm{cm}$ memberikan hasil yang lebih baik pada variabel tinggi tanaman, jumlah daun, luas daun, bobot kering tajuk, bobot kering akar dan bobot kering tanaman pakcoy.

Demplot aplikasi penggunaan pestisida nabati dilakukan di lahan demplot. Pesnab yang digunakan adalah pestisida nabati ekstrak daun bawang, cabai, dan tembakau dan sudah sering digunakan untuk pengendalian hama maupun penyakit di tanaman sayuran daerah lain. Salah satu jenis tumbuhan yang dapat dimanfaatkan sebagai bahan baku pestisida nabati adalah bawang putih dan cabai (Setiawati, 2008). Sebagai kontrol adalah penanggulangan hama penyakit secara manual yang biasa dilakukan oleh kelompok para ibu KWT. Hasil menunjukkan bahwa terdapat fisik yang lebih baik dari tanaman yang menggunakan pestisida hayati. Daun hijau mulus karena tidak dimakan ulat. Rasa sayuran yang dipanen juga lebih disukai karena memberikan rasa yang lebih manis (tidak pahit). Menurut Galingging (2010) hama yang terkena semprotan air cabai akan mongering dengan membrane sel rusak kehabisan cairan. Ratna dalam Tigauw (2015) menyatakan bahwa ekstrak bawang putih yang paling berpengaruh terhadap kematian hama kutu daun persik adalah konsentrasi $100 \%$ dan frekuensi waktu penyemprotan yang paling efektif setiap hari dengan persentase kematian $88,55 \%$.

Penelitian Susilowati (2005) menunjukkan bahwa semakin tinggi konsentrasi ekstrak daun tembakau mempengaruhi efektifitasnya sebagai insektisida. Oleh karena itu cabai dapat dijadikan bahan baku pembuatan pestisida nabati yang ampuh untuk mengendalikan kutu, tungau, ulat, dan cacing perusak akar. Demplot aplikasi teknis budidaya sayuran organik yang benar mulai dari proses pengolahan tanah, pembibitan, penanaman, pemupukan, pemeliharaan, panen, hingga pasca panen dilakukan di lahan demplot. Sebagai kontrol adalah teknis budidaya sayuran organik yang biasa dilakukan oleh KWT. 


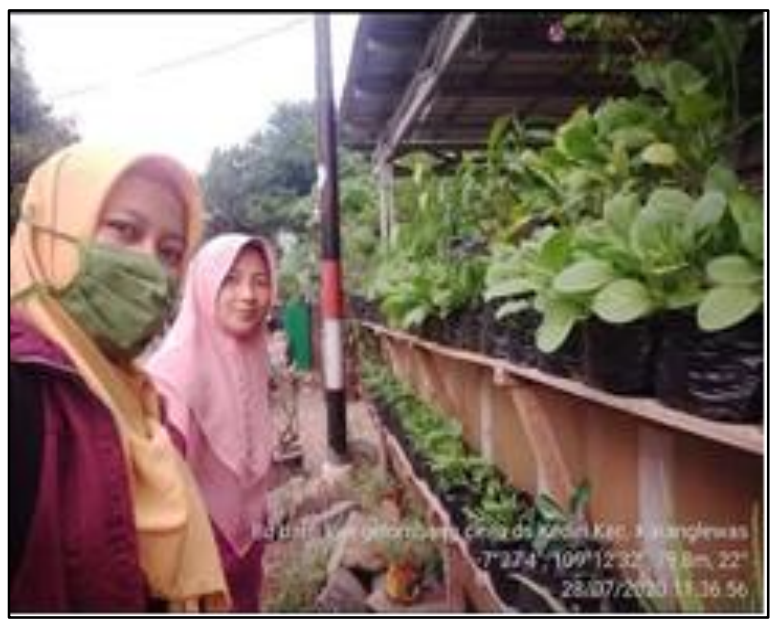

Gambar 3. Pendampingan Pemeliharaan

Tabulampot Sayuran Organik

Agenda terakhir adalah manajemen pembukuan usaha dan penguatan kelompok. Kegiatan pencatatan usaha budidaya dan penjualan sayuran organik selama ini belum dilakukan secara tertib. Sehingga tidak dapat dapat diketahui seberapa keuntungan dan modal yang diperlukan untuk meningkatkan usaha. Tim pengabdian memberikan pelatihan mengenai pencatatan kegiatan usaha, menginfentarisir asset kelompok dan memetakan peluang perluasan pemasaran dan produk turunan. Untuk meningkatkan kekompakan kelompok juga dilakukan pendampingan dan penguatan kelompok melalui agenda pertemuan rutin, mempertemukan dengan perangkat desa dan penyuluh pertanian agar kegiatan usaha juga mendapatkan dukungan dari pemangku kebijakan, dan mengikutkan pada kegiatan pameran sekaligus sebagai upaya perluasan pasar. Tabel 1. Target Capaian Kegiatan Pendampingan

\begin{tabular}{lcc}
\hline \multicolumn{1}{c}{ Parameter } & Sebelum & Sesudah \\
\hline $\begin{array}{l}\text { Pengetahuan tentang } \\
\text { budidaya sayuran organik } \\
\text { yang efisien }\end{array}$ & 50 & 80 \\
$\begin{array}{l}\text { Ketrampilan tentang } \\
\text { pembuatan dan penggunaan }\end{array}$ & & \\
$\begin{array}{l}\text { pestisida nabati secara } \\
\text { sederhana }\end{array}$ & 25 & 75 \\
$\begin{array}{l}\text { Kuantitas dan kualitas } \\
\text { produksi sayuran organik }\end{array}$ & 50 & 80 \\
$\begin{array}{l}\text { Ketrampilan tentang } \\
\text { pembuatan garam kelor dan } \\
\text { teh kelor }\end{array}$ & 20 & 70 \\
\hline
\end{tabular}

Target luaran yang dicapai dalam kegiatan ini menunjukkan hasil yang cukup menuaskan. Peningkatan pengetahuan tentang budidaya sayuran organik yang efisien sebesar $80 \%$. Peningkatan ketrampilan tentang pembuatan dan penggunaan pestisida nabati secara sederhana dari bawang putih, cabai, dan tembakau sebesar lebih dari $70 \%$. Peningkatan kuantitas dan kualitas produksi sayuran organik minimal sebesar $50 \%$. Peningkatan ketrampilan tentang pembuatan garam kelor dan teh kelor sebesar lebih dari $70 \%$. Target capaian luaran ditampilkan pada Tabel 1.

\section{KESIMPULAN}

Kegiatan pendampingan oleh tim pengabdi mampu meningkatkan ketrampilan anggota KWT Gelombang Cinta dalam budidaya sayuran organik di lahan pekarangan, penyediaan pupuk organik, dan pembuatan olahan berupa the daun kelor. Respon mitra dan perangkat desa cukup bagus.

\section{UCAPAN TERIMA KASIH}

Penulis mengucapkan terimkasaih kepada BLU UNSOED atas hibah pendanaan Pengabdian Kepada Masyarakat skim Penerapan IPTEKS dengan No Kontrak: P/1988/UN23/14/PM/2020, LPPM Universitas Jenderal Soedirman

\section{DAFTAR PUSTAKA}

Dendy, P. (2014). Pengaruh Konsentrasi Pupuk Organik Cair Bio P2000Z dan Jarak Tanam Terhadap Pertumbuhan dan hasil tanaman caisim (Brasicca juncea L). Skripsi. Fakultas Pertanian UNSOED.

Galingging, R.Y. (2010). Pengendalian Hama Tanaman Menggunakan Pestisida Nabati Ramah Lingkungan. https://kaltenglitbang.deptan.go.id/diakses 10 November 2019

Komaruddin. (2014). Aplikasi pupuk organik cair pada berbagai konsentrasi dan jarak tanam pertumbuhan dan hasil pakcoy (Brassica chinensis, L). Skripsi. Fakultas Pertanian UNSOED.

Marpaung, A.E., Karo, B \& Tarigan, R. (2014). Pemanfaatan Pupuk Organik Cair dan Teknik Penanaman dalam Peningkatan Pertumbuhan dan Hasil Kentang. J. Hort. Vol 24 (1). 49-55 pp.

Saptono, E \& Andoko, A. (2008). Bertanam Sayuran Organik di Pekarangan. Agromedia Pustaka. Jakarta.

Setiawati, W. (2008). Tumbuhan Bahan Pestisida Nabati dan Cara Pembuatannya untuk Pengendalian Organisme Pengganggu Tumbuhan (OPT). Balai Penelitian Tanaman 
Sayuran. Bandung).

Supriati, Y., Yulia, Y \& Nurlela, I. (2008). Taman Sayur dan 19 Desain Menarik. Penebar Swadaya. Jakarta.

Susilowati, E. (2005). Identifikasi Nikotin dari Daun Tembakau Kering dan Uji Efektifitas Ekstrak Daun Tembakau sebagai Insektisida Penggerek Batang Padi. https://lib.unses.ac.id/ diakses 10 November 2019.
Sutariati, G. A. K., Safuan, Muhidin \& Hasid, R. (2018). Pengembangan Sayuran Organik Pada Lahan Pekarangan Untuk Meningkatkan Kesehatan Masyarakat di Kota Kendari. Abdimas. Vol 2 (2).

Tigauw, S.M.I., Christina, L.S \& Jusuf, M. (2015). Efektivitas Ekstrak Bawang Putih dan Tembakau terhadap Kutu Daun pada Tanaman Cabai. Eugenia. Vol 21 (3). 135-141 pp. 
2 Jurnal Pangabdhi 